Windle, J. (2011). 'Poppies for Medicine in Afghanistan: Historical Lessons from India and Turkey'. Journal of Asian and African Studies. Vol. 46(6), pp. 663-677. Pre-print copy.

\title{
Poppies for Medicine in Afghanistan: Historical Lessons from India and Turkey
}

\author{
James Windle
}

\begin{abstract}
This study examines India and Turkey as case studies relevant to the Senlis Council's 'poppies for medicine' proposal. The proposal is that Afghan farmers are licensed to produce opium for medical and scientific purposes. Here it is posited that the Senlis proposal neglects at least three key lessons from the Turkish and Indian experiences. First, not enough weight has been given to diversion from licit markets, as experienced in India. Second, both India and Turkey had significantly more efficient state institutions with authority over the licensed growing areas. Third, the proposal appears to overlook the fact that Turkey's successful transition was largely due to the use of the poppy straw method of opium production. It is concluded that, while innovative and creative policy proposals such as that of the Senlis proposal are required if Afghanistan is to move beyond its present problems, 'poppies for medicine' does not withstand evidence-based scrutiny.
\end{abstract}


Windle, J. (2011). 'Poppies for Medicine in Afghanistan: Historical Lessons from India and Turkey'. Journal of Asian and African Studies. Vol. 46(6), pp. 663-677. Pre-print copy.

The 1961 United Nations (UN) Single Convention on Narcotic Drugs (United Nations, 1961) restricts the use and production of opium to medical and scientific purposes. All other efforts to produce opium are illicit. The Single Convention additionally provides a monitoring framework which ensures that the legal production of opium remains highly regulated. State narcotics boards must not only take stringent measures to monitor and control opium production but are subject to monitoring by the International Narcotics Control Board (INCB), and thereby accountable to the international community. In practice this means that a country cannot simply start producing opium for medical and scientific purposes, but must have the approval of the international community. It can only obtain that approval via INCB and the United Nations Commission on Narcotic Drugs (CND), the international bodies which promote the integrity of the legal drug trade and coordinate efforts to tackle the illegal trade. A national-level proposal that convinces the member states of CND and the appointed board members of the INCB must be watertight.

Since 2005, the Senlis Council (now renamed the International Council on Security and Development) have lobbied governments and inter-governmental bodies to support its proposal for a 'poppies for medicine' industry in Afghanistan. ${ }^{1}$ In brief, the proposal is that the government of Afghanistan should license some farmers to cultivate opium poppies from which the state produces medicinal morphine to sell to third-world nations at a lower price than in current markets (Bhattacharji and Kamminga, 2010; Van Ham and Kamminga, 2007). It is currently proposing the implementation of a pilot project to analyze outcomes and inadvertent consequences (Kamminga, 2011). Creative and innovative proposals such as this are to be welcomed as the illicit opium trade has become one of the biggest risks to Afghanistan's economic and political stability. However, the Senlis proposal for Afghanistan warrants scrutiny not least because of the potential ramifications for international opium and heroin markets, both licit and illicit, but also because of the potential implications for Afghanistan as a nation state. It is the need to ensure that any benefits of legal opium production must clearly outweigh any potential costs and risks in the context of a new and fragile democracy, which motivated the present study.

\footnotetext{
${ }^{1}$ For the Senlis media campaign between 2008 and mid-2011 please search Paul Burton, Norine MacDonald and Jorrit Kamminga on Nexis-Lexis to access the numerous interviews with high-profile western media such as The Times, the Washington Times and The International Tribune Herald.
} 
Windle, J. (2011). 'Poppies for Medicine in Afghanistan: Historical Lessons from India and Turkey'. Journal of Asian and African Studies. Vol. 46(6), pp. 663-677. Pre-print copy.

The 'poppies for medicine' proposal is supported by two case studies of the Indian and Turkish regimes. The basis of this paper is a critical analysis of these two pieces of research. By drawing upon a review of these regimes, it is suggested that the Senlis proposal neglects at least three key lessons from these experiences. First, not enough weight has been given to diversion from licit markets as experienced in India. Second, both India and Turkey had, and have, significantly more efficient state institutions with authority over the licensed growing areas. Third, the proposal appears to overlook the fact that Turkey's successful transition was largely due to the use of the poppy straw method of opium production.

The lessons from India and Turkey must be envisaged in the Afghan context. Here, the extremely-fragile nature of the Afghan nation-state and the lack of the rule of law are key factors. The authority of the Afghan state is weak in poppy-growing areas; corruption is endemic to most Afghan institutions including the administration of criminal justice which is also significantly under-resourced. Further, the country lacks the transport infrastructure required for a licit opium industry and there is the possibility that licensed opium production would affect only a small percentage of Afghans and generate resentment elsewhere. Consequently, based upon the analyses of experience in India and Turkey it is concluded that Afghanistan is not presently in a position to undertake a 'poppies for medicine' regime.

To set the scene, the next section outlines the Senlis 'poppies for medicine' proposal and summarizes some critiques already expressed by policy analysts. This is followed by background information on, then analysis of, the Indian and Turkish licit opium industries and their use as case studies in support of the Senlis proposal. A review of some inefficiencies of the Afghan state which would act as a barrier to implementation of the plan is then undertaken. The concluding section draws together the various strands of evidence in order to assess the likelihood for success of the 'poppies for medicine' proposal.

\section{Overview of the 'Poppies for Medicine' Proposal}

The Senlis Council (2007) published the 'poppies for medicine' proposal in 2005. In the proposal the Afghan state would license village groups to cultivate opium poppies and process the extracted opium into morphine tablets, from which the state would produce medicine for domestic or foreign redistribution. Once licensed a village Shura ${ }^{2}$ would

\footnotetext{
${ }^{2}$ The Shura is a traditional dispute resolution mechanism operating in Afghanistan in which a council of elders interpret customary and Islamic laws passed down through generations. The Shura is found
} 
Windle, J. (2011). 'Poppies for Medicine in Afghanistan: Historical Lessons from India and Turkey'. Journal of Asian and African Studies. Vol. 46(6), pp. 663-677. Pre-print copy.

allocate jobs within the village. Farmers, farm labourers, security guards, laboratory technicians and administrators would be hired and, if required, trained. The Shura would monitor and record the process by first estimating the amount of produce each farmer should yield from their land and then monitoring compliance with this estimation. If a farmer fails to produce the promised yield at harvest, without satisfactory explanation, this would indicate diversion. Any evidence of diversion by one village member would result in the rescission of the village license and possible criminal prosecution by the state and/or Shura against the individual.

The Afghan National Police (ANP) would partner villagers in protecting their produce from external threats during cultivation, storage and transit. International development organizations would monitor the quality of produce. The Shura would be required to allocate an undefined percentage of all profits to the development of the village, in an attempt to diversify economic activity, with a long-term goal of 'phasing out' licit and illicit poppy cultivation. International development organizations would advise on strategic spending. The two primary objectives of the proposal are to reduce illicit opium production within Afghanistan and supply more affordable opiate-based painkillers to less-developed nations, in which there is a deficit of affordable opiate-based painkillers.

The proposal for legal opium production in Afghanistan garnered a mixture of support and criticism (see, e.g., Attaran and Boozary, 2011; Fawthrop, 2005; The Lancet, 2005; Polanyi, 2006; Tanter, 2011) $)^{3}$ from politicians, the media and academics. Policy analyst critiques have been based upon five general themes which shall be briefly summarized here (see Bhattacharji and Kamminga, 2010, for a defence of the criticisms). First, while around 90\% of global medicinal opiates are consumed in North America and Europe, this reflects not a deficit of supply, as Senlis suggest, but rather inadequate access and demand from developing nations (Chouvy, 2008; Grare, 2008; INCB, 2008). Second, Afghan opium would have to compete with existing licit producers such as Australia, India and Turkey. Third, the initiation of such a project in the more secure areas of Afghanistan would likely cultivate resentment within the less secure areas, where poppy cultivation is at its highest. Fourth, licit

within areas dominated by Hazara, Tajiks and Uzbecks. Similar mechanisms exist in Pashtun areas referred to as a Jirga. See Wardak, 2006.

${ }^{3}$ For links to support for the proposal from western political parties and government committees see http://www.senliscouncil.net/modules/P4M/support 
Windle, J. (2011). 'Poppies for Medicine in Afghanistan: Historical Lessons from India and Turkey'. Journal of Asian and African Studies. Vol. 46(6), pp. 663-677. Pre-print copy.

opium cultivation is not a developmental panacea; the likely licit income would be lower than the current illicit income (Chouvy, 2008). Last, the Afghan state is not prepared for a 'poppies for medicine' industry. There is large scale conflict, instability, corruption and inefficiencies within the criminal justice and bureaucratic system (Felbab-Brown, 2007).

Most importantly, Zulmay Afzali (2008), a spokesperson for the Afghan Ministry of Counter Narcotics, has agreed with many of these critiques stating that, if a global deficit did exist, then the major licit producers would have already filled it. The challenges of regulating opium production in insecure areas is also acknowledged, as is the potential for the proposal to increase conflict, stating that licensing a small number while eradicating the remainder of farmers' crops would be an invitation to a return to civil war.

It is not the intention of this paper to re-assess or reiterate these issues; however, some overlap is inevitable. Rather, it intends to evaluate the use of India and Turkey by Senlis as case studies in support of the overall proposal.

\section{An Introduction to the Indian and Turkish Opium Trades}

India and Turkey have long histories of supplying the market for both licit and illicit opium. Opium production in India was constrained, to a point, by strong bureaucratic and criminal justice mechanisms from 1799 onwards. The control process has improved its administrative and technological efficiency yet continues with the basic structure established in 1799 . Unlicensed opium farming was prohibited and subject to stringent punishment. Opium poppy farmers were licensed to farm, and produce an amount demanded by, and sold only to, the state, at a fixed price. At the end of each season, the farmers transported produce to state opium agents for weighing and examination for adulterants. The opium would then be transported under armed guard to opium refining factories (Newman, 1989; Richards, 1981; Windle, 2011).

Until 1936, the Indian export controls were often weak, sometimes deliberately so, resulting in opium being smuggled into countries which prohibited its importation, most notably China (Haq, 2000). The export controls currently conform to international regulations imposed by the Single Convention.

Turkish opium suffered similarly weak export controls and supplied large illicit markets. However, Turkey never benefitted from the regulatory controls that had been 
Windle, J. (2011). 'Poppies for Medicine in Afghanistan: Historical Lessons from India and Turkey'. Journal of Asian and African Studies. Vol. 46(6), pp. 663-677. Pre-print copy.

implemented in India by the British during colonial rule (Poroy, 1981). This meant that, until the early 1970s, Turkish opium was one of the primary sources for the global illicit opium and heroin markets (Bulletin of Narcotics, 1953; INCB, 1971; Murphy and Steele, 1971; West, 1992). In response to international pressure, particularly from the United States (US), the government of Turkey first banned opium cultivation in 1971. The prohibition was dropped in 1974 in favour of a strict licensed control system, based upon the manufacture of poppy straw (Brundage and Mitchell, 1977; Spain, 1975).

As illustrated in Figure 1, since the 1980s India and Turkey have consistently been two of the leading suppliers of medicinal and scientific opium to the global market. India, during the 1970s exerted a near monopoly on the licit opium market (Haq, 2000).

Figure One

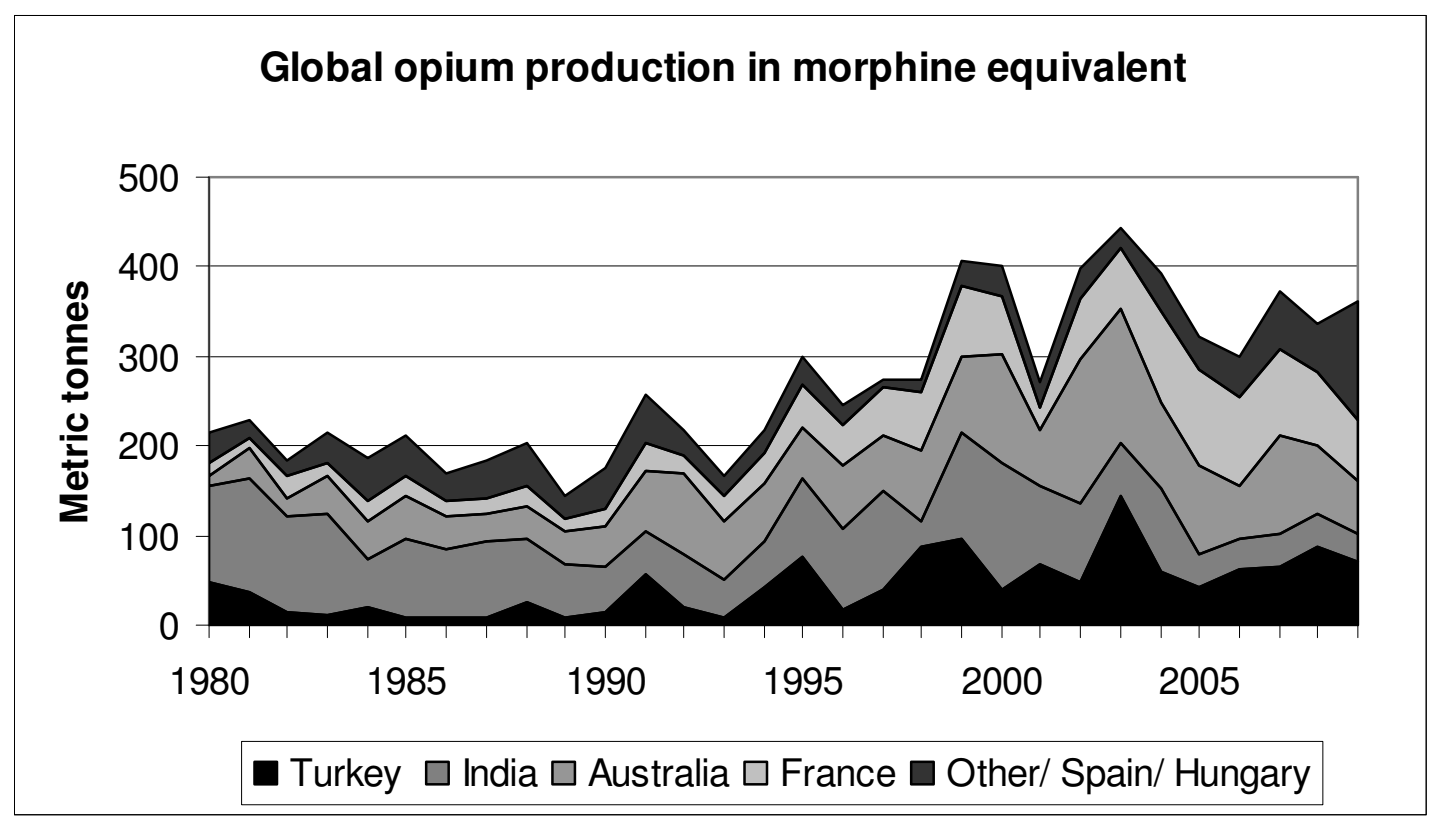

Source: Adapted from various INCB Annual Reports.

\section{Lessons from India}

From 1996 to 2001, Romesh Bhattacharji was Narcotics Commissioner of the Indian Central Bureau of Narcotics (CBN), the government department which controls and overseas the licit opium trade. In 2007 he published a report with the Senlis Council titled India's Experiences in Licensing Poppy Cultivation for the Production of Essential Medicines (Bhattacharji, 2007). The report argued that the experience of India's involvement in the licit trade in 
Windle, J. (2011). 'Poppies for Medicine in Afghanistan: Historical Lessons from India and Turkey'. Journal of Asian and African Studies. Vol. 46(6), pp. 663-677. Pre-print copy.

medicinal and scientific opium lent support to the Senlis 'poppies for medicine' proposal for Afghanistan. Bhattacharji had conducted field research in Afghanistan to complement his extensive experience with the Indian opium trade. However, the report was based solely on his personal knowledge and experience. That is, it lacked a foundation in the relevant literature and knowledge base, and consequently it overlooked some fundamental criticisms and issues relating to the mechanisms for the control of licit opium production. Chief amongst these is the issue of the diversion of opium from licit channels.

\section{Diversion}

'Diversion' is the rather innocuous-sounding technical term by which drug policy refers to theft. Diversion of licit opium in India is as old as the trade itself and was documented during colonial times (Watt, 1908; Windle, 2011). Yet arguably a significant weakness of the Bhattacharji/Senlis report, and the overall Senlis proposal for Afghanistan, is the lack of attention paid to diversion from the licit Indian trade to the black market. Precise nationallevel estimates of the diversion rate are largely conspicuous by their absence (Mansfield, 2001; US State Department, 2009). Nonetheless, many academic and government researchers have produced educated estimates. These have ranged from 10\% in the mid-1980s (National Narcotics Intelligence Consumers Committee (NNICC), 1981, 1988), and 6-7\% (INCB, 1993), 25\% (Laurent et al., 1996), and upwards of 50\% (Haq, 2000) in the 1990s. Estimates in the first decade of the 21 st century range from between 10\% (US State Department, 2008) ${ }^{4}$ and 30\% (Mansfield, 2001). ${ }^{5}$ Foreign diplomats stationed in India have suggested that the $10 \%$ estimate is too conservative (Paoli et al., 2009).

Bhattacharji acknowledges diversion at around 20\%, illustrating his point with an example of the Indian province of Uttar Pradesh were some licensed farmers were able to

\footnotetext{
${ }^{4}$ The US State Department reports diversion between 10 and 30\%. No supporting evidence is published for this figure.

${ }^{5}$ Paoli et al. (2009) mixed the high-end US State Department estimate of 30\% (interviews with foreign diplomats stationed in India pointed to the lower-end being too conservative) with potential opium produced from reported 'non-harvested' opium poppy crops (i.e. when farmers report that they were unable to harvest their crops through poor weather conditions, strike action or such) to conclude an average diversion of 200 to 300 tonnes annually between 1996 and 2004. If these estimates were to be included in Figure 2 or Figure 3 then the line would fluctuate between levels higher than the 50\% parameter and lower than the $30 \%$ parameter, but never as low as the $10 \%$ parameter.
} 
Windle, J. (2011). 'Poppies for Medicine in Afghanistan: Historical Lessons from India and Turkey'. Journal of Asian and African Studies. Vol. 46(6), pp. 663-677. Pre-print copy.

cultivate poppies which produced almost double the opium yield per hectare of their neighbours (Bhattacharji, 2007). It is also worth noting that, if the yield was almost double then, for this example at least, the rate of diversion could be, by inference, close to $50 \%$. However, even if 'only' $20 \%$ of opium is routinely diverted, this defines at least one parameter and limitation of the Indian model.

Higher diversion rate estimates were derived by the former Mandsaur Deputy Narcotics Commissioner, Karan Sharma, who conducted an experiment in 1994 to highlight how high the Minimum Qualifying Yield (MQY) should be set. The MQY is a measure of yield set annually by the CBN which specifies the minimum kilograms of opium per hectare which each licensee must deliver. If the MQY is not met then, with the implication being that the remainder was sold illegally, the farmer loses the right to secure licenses for opium farming. Sharma cultivated, on a model farm, $62 \mathrm{~kg}$ of opium from one hectare, while the MQY, at that time, was $40 \mathrm{~kg}$ per hectare. Sharma further claimed that careful and experienced farmers could produce as much as 100kg per hectare (Haq, 2000).

After interviewing Indian nationals involved in the licit trade in 2001, David Mansfield (2001) similarly concluded that average yields of $60-65 \mathrm{kgs}$ can be obtained from one hectare, while $80-100 \mathrm{~kg}$ is possible. These estimated yields suggest diversion rates - assuming that little over the MQY is surrendered to the state - of between 35 and $60 \%$.

A separate indicator of the extent of diversion from licit channels is that, since the mid1980s, significant numbers of heroin-processing laboratories have been detected in India (INCB, 1993; NCB, 1993), many within licensed opium poppy growing regions (Mansfield, 2001; Paoli et al., 2009).

\section{Diversion in the Context of the Global Illicit Opium Traffic}

The methodological reasoning of many of the estimations expressed earlier is not evident. Some may be little more than expert opinion. In the absence of a definitive study of Indian diversion and, due to the uncertainty over the precise diversion rate, the amount of opium diverted from India's licit production is here estimated using different diversion rate parameters. A 'low' diversion rate estimate of 10\%, a 'medium' estimate of $30 \%$ and a 'high' estimate of $50 \%$ are used. 
Windle, J. (2011). 'Poppies for Medicine in Afghanistan: Historical Lessons from India and Turkey'. Journal of Asian and African Studies. Vol. 46(6), pp. 663-677. Pre-print copy.

By employing these parameters further light can be shed on the Bhattacharji paper by placing the diversion of Indian opium in the context of the global illicit opium traffic. Figures 2 and 3 show the amount of Indian opium diverted using these parameters and set against the backdrop of estimated illicit opium production in Afghanistan, Burma (Myanmar) and Laos, which, in the most recent decade, have been the three most significant source countries. Figure 3 suggests that, if India's diversion rate has exceeded 10\%, then its contribution to the illicit opium trade has often surpassed that of Laos. Put another way, India may well be the world's third-ranked producer of illicit opium after Afghanistan and Myanmar.

Figure Two

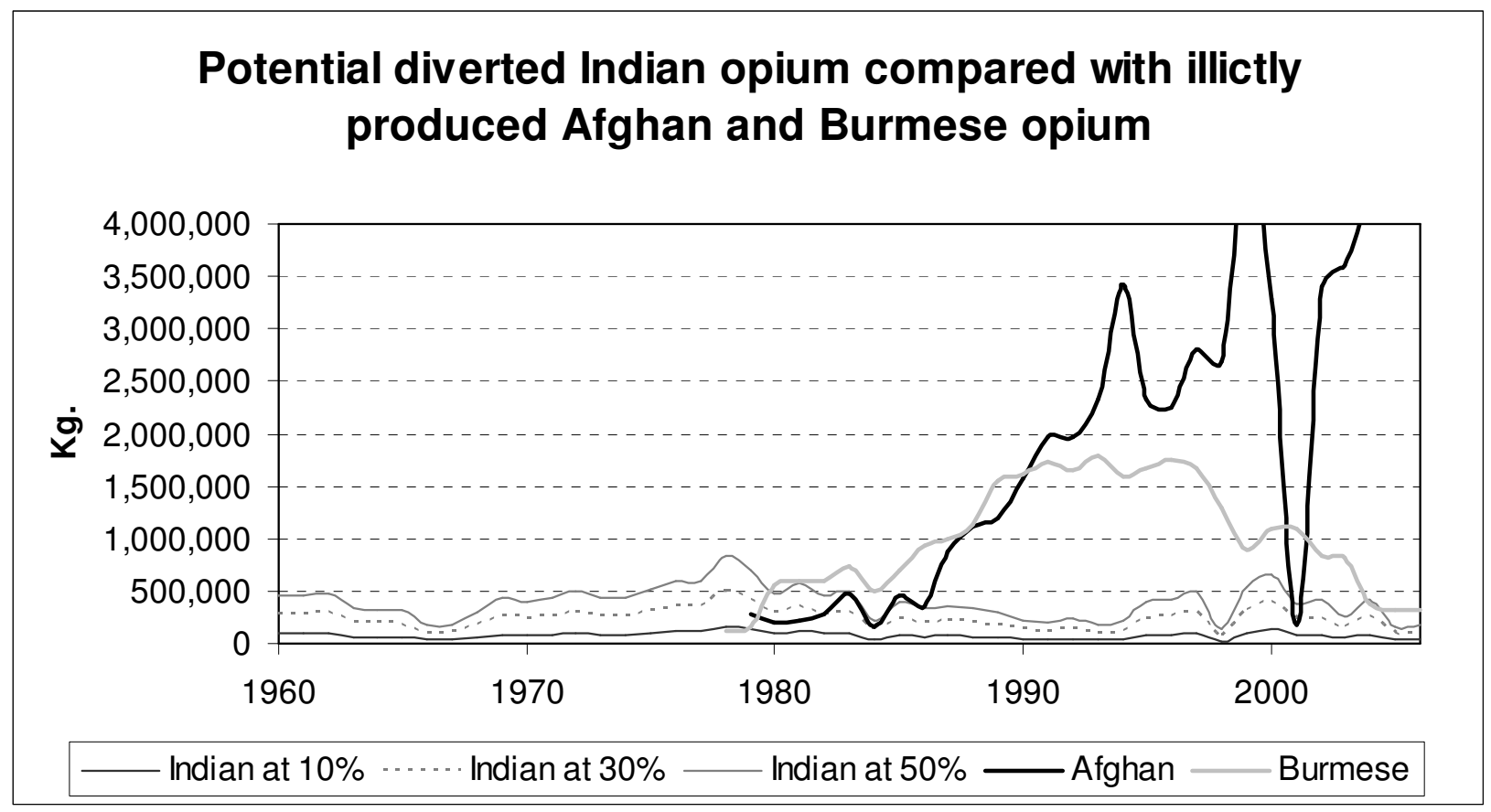

Sources: Adapted from various UNODC World Drug Reports and Deshaprabhu. The Wealth of India: Raw Materials, 1966. 
Figure Three

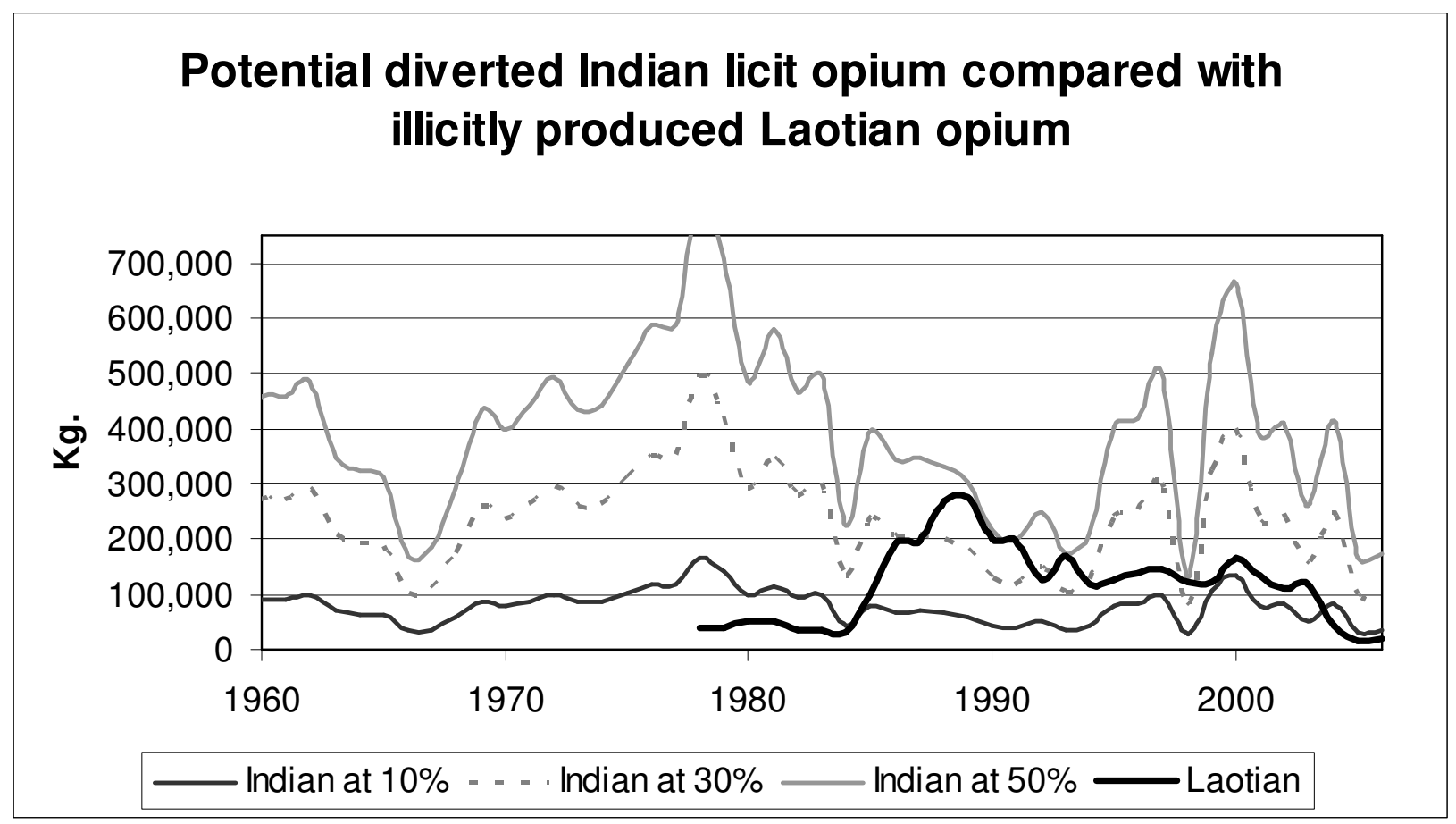

Sources: Adapted from various UNODC World Drug Reports and Deshaprabhu. The Wealth of India: Raw Materials, 1966.

Viewed in a different context, the low estimate for Indian diversion in 2006 of $34,487 \mathrm{~kg}$ is higher than the amount seized that year in many western countries: the US seized $1,725 \mathrm{~kg}$ and Australian seized $65 \mathrm{~kg}$ of heroin, equivalent to $17,250 \mathrm{~kg}$ and $650 \mathrm{~kg}$ of opium respectively. Seizures in Western Europe totalled 8,352kg of heroin or $83,520 \mathrm{~kg}$ of opium equivalent (United Nations Office of Drugs and Crime (UNODC), 2008) and, while higher than the 'low' estimate of Indian diversion derived here, this is significantly lower than the higher estimates. Put another way, current diversion from India probably outweighs a significant part of the global supply reduction effects of Western law enforcement (Windle, 2011).

Clearly the diversion rate will vary and is not constant - that is merely a simplifying assumption made here for illustrative purposes. For example, the contraction of the number of licensed opium farmers in India in the early 1990s may have resulted in diversion being closer to the higher diversion rate parameters (Burger, 1995). Conversely, technological advances in crop monitoring in the first decade of the 21 st century, coupled with higher MQYs of the 1990s (US State Department, 2002, 2009) may have resulted in diversion 
Windle, J. (2011). 'Poppies for Medicine in Afghanistan: Historical Lessons from India and Turkey'. Journal of Asian and African Studies. Vol. 46(6), pp. 663-677. Pre-print copy.

falling closer to the low diversion rate (Windle, 2011). That said, it is of note that the inability of the government of India to effectively measure diversion may itself illustrate the lack of control the state has over its licit industry.

\section{Lessons from Turkey}

Published by the Senlis Council in 2007, Jorrit Kamminga released The Political History of Turkey's Opium Licensing System for the Production of Medicines: Lessons for Afghanistan (Kamminga, 2007). This was followed in 2011 by Opium Poppy Licensing in Turkey: A Model to solve Afghanistan's Illegal Opium Economy? (Kamminga, 2011). The title is arguably somewhat of a misnomer. It does offer a political history of the opium licensing system. However, it does not appear to identify lessons for Afghanistan other than to point to the well-known fact that the US and UN supported Turkey in developing a licit industry from a sparsely regulated one.

It is of note that Turkey's licit opium industry almost certainly reduced the rate of diversion over time. From 1933 onwards, the government of Turkey had been increasing its regulatory control over the licit trade and attempting to prevent diversion. Up to 1971 the control system was based upon an 'Opium Declaration System'. The government formed estimates of how much opium Turkey should be producing, based on anticipated demand and stock levels from the preceding growing season. Thereafter, the Ministry of Agriculture calculated how much land was required to produce this amount and how many provinces should be allowed to cultivate poppies. However, unlike the Indian licensing system, the farmer was not told how much to plant but was required to inform a village representative how much they were willing to plant and the expected yield. The estimates were passed to the Ministry of Agriculture. The farmer was then expected to maintain production at the selfimposed level. A license acknowledging this was not required (Murphy and Steele, 1971). In short, therefore, the licit production of opium in Turkey was regulated before the 1971 ban, but the regulations were rather loose and, due to their generously flexible scope, left little requirement for enforcement but plenty of scope for diversion.

Kamminga's report does not give details of the mechanism by which the improvement in opium control was achieved after 1971 other than to note US and UN assistance. It was by the introduction of the poppy straw process for the production of licit opium. The production of opium from poppy straw is significantly different from that of poppy pods, and was 
Windle, J. (2011). 'Poppies for Medicine in Afghanistan: Historical Lessons from India and Turkey'. Journal of Asian and African Studies. Vol. 46(6), pp. 663-677. Pre-print copy.

compatible with a ban upon the harvesting and collection of poppy gum from lanced opium poppy pods. Due to the nature of the poppy straw production process, outlined briefly here, there is far less opportunity for the diversion of opium. In the system introduced in Turkey in the 1970s, the poppy plant is cultivated in the same manner as elsewhere, whether India or Afghanistan. However, at harvest the farmer is prohibited from incising the poppy pods to collect the opium gum within. The state monitors growing fields to ensure that no pods have been incised. Farmers cut and crush the poppies instead of directly extracting the opium themselves. The crushed poppies represent the poppy straw which is then sold to the state. Using expensive technology that is not generally available, the morphine is extracted (Mansfield, 2001).

Table One

\begin{tabular}{l|l|l|l|l} 
& $\begin{array}{l}\text { Control of } \\
\text { corruption } \\
\text { (percentile rank) }\end{array}$ & $\begin{array}{l}\text { Rule of law } \\
\text { (percentile } \\
\text { rank) }\end{array}$ & $\begin{array}{l}\text { Regulatory } \\
\text { control } \\
\text { (percentile rank) }\end{array}$ & $\begin{array}{l}\text { Government } \\
\text { effectiveness } \\
\text { (percentile rank) }\end{array}$ \\
\hline Afghanistan & 1 & 0.5 & 2.9 & 8.1 \\
\hline India & 47.3 & 56.2 & 46.1 & 57.3 \\
\hline Turkey & 59.4 & 53.3 & 59.7 & 63.5
\end{tabular}

Source: World Bank. (2008). World Wide Governance Indicators.

It is curious that Senlis uses the two case studies as illustrative modules and then ignores the findings of scholars who have noted that the Turkish module, due to its reliance on the poppy straw process, is the more effective at limiting diversion (Mansfield, 2001; West, 1992). An expression of Turkish success is that, from 1976 onwards, the International Narcotics Control Board, the quasi-judicial body which is mandated under the Single Convention to monitor the licit opiate trade, has consistently reported that no diversion has been reported to them, expressing their satisfaction with the Turkish poppy straw process. During and beyond the 1980s, the paragraph the INCB used to express these successes was replaced with concern over the use of Turkey as a trafficking route and location for heroin manufacturing. As Turkey has continued to prove its ability to prevent diversion the international community lessened the need to reward; minimal diversion became the norm. However, the Senlis proposal is based on the Indian experience and control measures to a 
Windle, J. (2011). 'Poppies for Medicine in Afghanistan: Historical Lessons from India and Turkey'. Journal of Asian and African Studies. Vol. 46(6), pp. 663-677. Pre-print copy.

much greater extent. Of the two case studies, therefore, it would appear the less efficient has been chosen as the model for Afghanistan.

\section{The Relative Inefficiency of the Afghan State}

Bhattacharji and Kamminga's discussions fail to acknowledge the significant differences in efficiency between India, Turkey and Afghanistan. An analysis of some key determinants from the World Bank World Governance Indicators (2008a) indicates the overall differences. As illustrated in Table 1, both Turkey and India are globally ranked within the middle percentiles for all indicators; Afghanistan is ranked amongst the least efficient nations in the world for all indicators. The percentile rankings for the four indicators place Afghanistan on a level with, or below, such states as Somalia, Burma (Myanmar), Eritrea and Turkmenistan.

The protection of all levels of illicit activity by state employees is reported to be extremely high (Ghufran, 2007; Mansfield, 2007; Shaw, 2007). The 'criminalization' of the ANP has also been reported as a problem of epidemic proportions, with reports of extortion and robbery by officers (Windle and Farrell, 2010). Afghanistan has an existing, and is developing a more extensive, body of criminal and civil law that meets international standards. However, largely due to corruption, an inadequate pool of educated workers and resource inadequacies, there remains a huge void between the rights and procedures expressed under state law and the ability of the state to enforce them (Windle and Farrell, 2010).

Of great significance to the project is that the Afghanistan transport infrastructure is highly inadequate. Its system of roads is reported as amongst the worst in the world. It has no railway infrastructure and is landlocked, with over 2,000 kilometres to a sea port. Its air transport infrastructure is seen as too uncertain for many international air carriers (World Bank, 2008b). Further, there are many reports of insurgents, criminals and ANP officers robbing and extorting money from travellers on state highways, making many unusable (The Economist, 2008; Ghufran, 2007; US State Department, 2007). There does not seem to be a road, or other transport infrastructure, with the capacity to support an export-based industry where opium - a valuable commodity with inherent attractions for thieves - could be reliably transported from remote rural areas to processing factories and beyond for export or domestic re-distribution. 
Windle, J. (2011). 'Poppies for Medicine in Afghanistan: Historical Lessons from India and Turkey'. Journal of Asian and African Studies. Vol. 46(6), pp. 663-677. Pre-print copy.

Further, both Turkey and India have long histories of relatively-efficient criminal justice and bureaucratic institutions. In India, the opium control system evolved with the evolving state system. In the 1970s, when Turkey strengthened its regulatory system, it already possessed a functioning state system. Conversely, Afghanistan is in the process of rebuilding after decades of violent conflict and institutional neglect.

\section{Further Analysis and Discussion}

The two case studies inform the overall 'poppies for medicine' proposal. This final section shall discuss the actual proposal as reported by Senlis Council (2007) and the relationship to the experiences of Turkey and India.

In the proposal, the state would license villages under three conditions: (1) that alternative crops are unavailable; (2) that the community is committed to the suppression of trafficking; (3) that the community is committed to creating diverse economies. It is also noted that access to road networks and land suitable for high-quality poppy would also be required.

The report fails to mention the level of security in the areas. Both India and Turkey prohibited cultivation in areas in which the state could not exert effective control: neither Bhattacharji nor Kamminga signify the importance of these measures. India de-licensed Himachal Pradesh in 1954-5 (Deshaprabhu, 1966) and Turkey prohibited cultivation in the border areas during the 1960s (INCB, 1967, 1971). Both realized that licensing would only work in areas in which the state presence was strong. Further, the level of violence in Himachal Pradesh and the border areas of Turkey was minimal in comparison to southeastern Afghanistan. One of the reasons for prohibition of the border areas of Turkey was due to the ease of movement of diverted opium across the border (Wishart, 1974). Further, up until the late 1970s, the Kurdish peoples who made up the majority of south-eastern poppy growing provinces of Urfa, Diyarbakir, Malatya, and Tuncel, had little economic integration with the state and tribal affiliations were significantly stronger than those to the state (Bozarslan, 2008).

A major limitation to successful implementation concerns the fact that $98 \%$ of opium is grown in the least secure areas of Afghanistan. These areas border the major consumption and transhipment markets of Pakistan and Iran. Most of the poppy-growing districts are largely inaccessible to UN agencies and non-governmental organizations (NGOs) and are 
Windle, J. (2011). 'Poppies for Medicine in Afghanistan: Historical Lessons from India and Turkey'. Journal of Asian and African Studies. Vol. 46(6), pp. 663-677. Pre-print copy.

under the authority of insurgents and/or organized criminal networks who have violently opposed eradication measures by the state in the past (UNODC, 2008). State criminal justice systems do not operate. In 2010, 7,120 casualties were reportedly a result of the Afghan insurgency; many were civilian targets employed by, or perceived to be supportive of, the state (US State Department, 2010). The potential to successfully implement a 'poppies for medicine' regime amid such high levels of conflict, in areas with minimal state control, is negligible.

In the proposal, Shuras rather than farmers are licensed. If one member defaults, including not meeting a minimum yield, the entire community loses its license. The reasoning is that it will limit diversion by increasing the social controls that the Shuras have over those involved. The Bhattacharji case study of India is used to support this process as social controls are exerted in India at the village level: a village representative, or Lambardar, is used as the conduit between the state and the villagers (who are individually licensed). It is this person who attempts to limit diversion and monitors compliance with the control system. Two studies of India's licit opium industry (Mansfield, 2001; Paoli et al., 2009), however, have critiqued the Lambardar system as being part of the problem. In interviews with Indian licit opium farmers it was reported that corrupt Lambardars take a percentage of illicit profits to 'turn a blind eye'. Further, in many parts of Afghanistan Jirgas/Shuras are reportedly hijacked by representatives not of the people but of local insurgent/criminal groups (Wardak, 2006). Thus, drawing from the experience of India, village level controls may not be the most appropriate control mechanisms. (While the punishment of an entire village for the transgressions of a minority would hardly seem to equate to fair drug policy.)

It is proposed that the ANP and village would be the primary barriers to 'outside influence' (i.e. insurgent/criminal groups). However, research has indicated that the ANP are notoriously corrupt. Also, that the Afghan National Army would train villagers as security guards could have two very serious repercussion. First, it would force villagers into conflicts with armed insurgent/criminal groups who would likely attempt to spoil the process through intimidation, acts of terrorism or theft of goods. Second, it could be looked upon as the creation of private militias, particularly if the state gave weapons to villagers employed for security purposes.

An auxiliary police/militia force was armed by the state in Pashtun areas in 2006. The force was disbanded due to anger at perceptions of one ethnic group being disarmed amid 
Windle, J. (2011). 'Poppies for Medicine in Afghanistan: Historical Lessons from India and Turkey'. Journal of Asian and African Studies. Vol. 46(6), pp. 663-677. Pre-print copy.

attempts to disarm other ethnic groups and reports of corruption and human rights abuses (Economist, 2008; Patel and Ross, 2007). It is not unlikely that similar problems would follow the creation of village-based private security forces.

A summary of the perceived positives of the policy is given by the Senlis Council:

Village-based 'poppies for medicine' projects would enable Afghanistan to defeat the illegal opium trade. Guaranteed to trigger economic development, 'poppies for medicine' projects would provide rural farming communities with access to the strategic assets necessary to diversify their economic activities and thus end their reliance on illegal poppy cultivation. 'Poppies for medicine' projects would not only allow for the controlled, sustainable phasing out of poppy cultivation, they would generate sufficient incentives for farming communities to cut links with drug traffickers. Interdiction and eradication would thereby be brought to a manageable level, by allowing distinctions to be made between the behaviour of those who cultivate poppy as a survival strategy, and the truly criminal behaviour of drug traffickers. (Senlis Council, 2007: 61)

However, this appears to have several limitations. First, the licit trade would be able to support just a small percentage of opium farmers. In 2008-9, around 2.9 million Afghans were involved in the illicit trade compared to just 72,478 in the Indian licit trade (in the 2005-6 season; Bhattacharji, 2007). If the size of the Afghan trade were to be equivalent to India's then just $2.5 \%$ would be licensed to work licitly. It is not entirely clear what would happen to the $97.5 \%$ of Afghans currently in the opium trade other than that they would be subject to the 'traditional' policy tools of alternative development and/or law enforcement. Further, Afghanistan has a large, very poor, rural population. It is not inconceivable that if 72,478 found work in the licit market, and no opium was diverted, then 72,478 Afghans in another area would be co-opted into growing opium. This replacement, driven by the price mechanism, would be similar to the replacement of low-cost drug mules who are arrested for trafficking.

Second, that the licensing system would cut the link between traffickers and farmers is an unsupported assumption. Using India as a model, it is likely that between 10 and $50 \%$ will be diverted to illicit channels. It was estimated that in Turkey, prior to the ban, two-thirds was 
Windle, J. (2011). 'Poppies for Medicine in Afghanistan: Historical Lessons from India and Turkey'. Journal of Asian and African Studies. Vol. 46(6), pp. 663-677. Pre-print copy.

diverted to illicit channels (Kayaalp, 2001). It has been suggested that $20 \%$ diversion from Afghanistan's licit crop would be considerably better than the current $100 \%$ entering the black market (Bhattacharji and Kamminga, 2010; Leeson, 2008). While perhaps an attractive argument, this presumes that Afghan diversion would be closer to the estimated lower levels of Indian diversion. Due to the security and bureaucratic concerns highlighted earlier it is not unreasonable to anticipate diversion rates closer to the higher Indian or pre-ban Turkish estimates.

One of the strongest arguments is that the process would build a reciprocal, trusting, relationship between the state and the peoples of licensed areas. However, this could be lost if licensed areas became targets of insurgents/criminal groups and, due to the high risk, the state and/or international development organizations backtracked on their commitments to the farmers.

\section{Conclusion}

The present study should not be interpreted as seeking to detract from the insightful research conducted by the Senlis Council, Jorrit Kamminga or Romesh Bhattacharji. It is the author's hope that this critique is taken as a complement to work that is sufficiently well-prepared that it needs to be given serious consideration. Afghanistan needs such proposals if it is to move beyond its current impasse relating to the illicit opium and heroin trade. Yet, at the same time, the potentially major importance of such proposals for the future of Afghanistan means that it behoves us to subject them to scrutiny, and to draw upon the available evidence. Having sought and assessed such evidence, the conclusion of this paper is that "poppies for medicine', as proposed by the Senlis Council in 2005, would not be to the benefit of Afghanistan or the international community, for the following key reasons:

- A substantial percentage of the opium produced by licensed farmers for the state would be diverted to the black market;

- State-licensed poppy farmers would be endangered;

- It may not be the most effective means of development, nor illicit crop control, for Afghanistan.

An example of the selective use of Indian and Turkish experiences in the proposals is the absence of the poppy straw method from the discussions on Turkey. The switch from opium gum to poppy straw production is the central element in Turkey's development from 
Windle, J. (2011). 'Poppies for Medicine in Afghanistan: Historical Lessons from India and Turkey'. Journal of Asian and African Studies. Vol. 46(6), pp. 663-677. Pre-print copy.

an illicit producer, with minimal regulations and high diversions, to a licit producer with stringent controls and minimal diversions. That the proposal would ignore this critical factor and largely base its licit opium control mechanisms on India, which has consistently experienced high levels of diversion, illustrates that the experiences of Turkey and India are selectively employed.

An in-depth feasibility study on the potential effectiveness of the poppy straw method in Afghanistan would have strengthened the proposal. However, it is likely that an independent study would conclude that the expense of the machinery used to convert poppy straw to morphine would be prohibitive. The monitoring process to prevent diversion to illicit channels would remain an issue of concern as the poppy straw process still requires intensive monitoring by the state to prevent farmers from extracting opium gum.

Another example of selective interpretation is that the Indian system licenses farmers on condition they meet the state imposed MQY, and rewards higher yields. The Senlis proposal requires the Shura to estimate expected yields, and there is no mention of the state imposing MQYs. This system appears to have a closer relationship to the 'Opium Declaration System' used, and highly criticized, as part of the regulatory weaknesses in Turkey before the opium ban.

An additional neglected factor is that both Turkey and India implemented licit controls in areas under state authority, where transport, criminal justice and bureaucratic infrastructures were relatively efficient. The Afghan state system as a whole lacks the attributes necessary for a 'poppies for medicine' programme. The Senlis proposal implies an environment in which rural Afghans can choose between licit and illicit livelihoods. However, as illustrated by the examples of India and pre-ban Turkey, farmers will likely choose a mixture of the two economies, selling part to the state and diverting part to the black market. That both India and Turkey possessed significantly more advanced bureaucratic and criminal justice institutions, better transport infrastructures, greater authority and less violence would suggest that the share going to the black market would be as high, or higher, than reported in either Turkey or India.

However, while the present conclusions may appear rather negative, they do not necessarily mean that a revised and improved version of 'poppies for medicine' could not be more appropriate for Afghanistan at some time in the future. Such a proposal could be re- 
Windle, J. (2011). 'Poppies for Medicine in Afghanistan: Historical Lessons from India and Turkey'. Journal of Asian and African Studies. Vol. 46(6), pp. 663-677. Pre-print copy.

considered if Afghanistan has made sufficient progress which, at minimum, would need to include:

- Significantly improved and stable key institutions of governance including the criminal justice system, bureaucratic and transport infrastructure;

- The writ of the state; that is, the rule of law has been extended with violence largely overcome in opium poppy-growing areas.

In short, Afghanistan needs to become more secure and efficient, and this will almost certainly take many years. To introduce 'poppies for medicine' at any time in the near future would, the evidence suggests, be premature.

\section{Acknowledgements}

I owe a debt of gratitude to Professor Graham Farrell and Sinead Drew for their insightful comments on early drafts of this paper.

\section{References}

Afzali Z (2008) Senlis Council is senseless for Afghanistan. Available at: http://mcn.gov.af/joomla/index.php?option=com_content\&task=view\&id=23\&Itemid= 29 (accessed 13 December 2009).

Attaran A and Boozary A (2011) For peace and pain: The medical legitimization of Afghanistan's poppy crop. Journal of Epidemiology and Community Health 65: 396-8.

Bhattacharji R (2007) Case study: India's experiences in licensing poppy cultivation for the production of essential medicines. Available at: http://www.poppyformedicine.net/modules/case_studies (accessed 11 March 2009).

Bhattacharji R and Kamminga J (2010) Poppy for medicine: An essential part of a balanced economic development solution for Afghanistan's illegal opium economy. Journal of Drug Policy Analysis 3(1). Available at: http://www.bepress.com/jdpa/vol3/iss1/art3 <http://www.bepress.com/jdpa/vol3/iss1/art3> (accessed 10 May 2011).

Bozarslan H (2008) Kurds and the Turkish state. In: Kasaba R (ed.) The Cambridge History of Turkey. Cambridge: Cambridge University Press, 333-57.

Brundage W and Mitchell W (1977) Towards an understanding of opium poppy production in Turkey. Journal of Asian and African Studies 12(1): 259-68.

Bulletin of Narcotics (1953) Illicit traffic in opium. Bulletin of Narcotics 1(2): 45-8. 
Windle, J. (2011). 'Poppies for Medicine in Afghanistan: Historical Lessons from India and Turkey'. Journal of Asian and African Studies. Vol. 46(6), pp. 663-677. Pre-print copy.

Burger A (1995) Narcotic Drugs: Security threat or interest to south asian states? In:

Weinbaum MG, Kumar C (eds) South Asia Approaches the Millennium: Re-examining National Security. Oxford: Westview Press, 167-83.

Chouvy P (2008) Licensing Afghanistan's opium: Solution or fallacy?. Caucasian Review of International Affairs 2(2): 101-6.

Deshaprabhu SB (1966) The Wealth of India: Raw Materials, Vol. 11. New Delhi: Publications and Information Directorate, CSIR.

The Economist (2008) The next surge. The Economist, 20 December.

Fawthrop T (2005) Opium: Curse or cure? The Guardian, 4 September.

Felbab-Brown V (2007) Opium Licensing in Afghanistan: Its Desirability and Feasibility. Washington, DC: The Brookings Institute.

Ghufran N (2007) Afghanistan in 2006: The complications of post-conflict transition. Asian Survey 47(1): 87-98.

Grare G (2008) Anatomy of a Fallacy: The Senlis Council and Narcotics in Afghanistan.

Centre for International Governance Innovation, Working Paper No. 34. Available at: http://www.cigionline.org/publications/2008/2/anatomy-fallacy-senlis-council-andnarcotics-afghanistan (accessed 18 May 2010).

Haq ME (2000) Drugs in South Asia: From the Opium Trade to the Present Day. New York: St. Martin's Press.

International Narcotics Control Board (INCB) (1967) Report of the INCB. New York: United Nations. E/INCB/1.

International Narcotics Control Board (INCB) (1971) Report of the INCB on its Work. New York: United Nations. E/INCB/13.

International Narcotics Control Board (INCB) (1993) Report of the International Narcotics Control Board for 1993. New York: United Nations. E/INCB/1993/1.

International Narcotics Control Board (INCB) (1994) Report of the International Narcotics Control Board for 1994. UN: New York. E/INCB/1994/1.

International Narcotics Control Board (INCB) (2008) Report of the International Narcotics Control Board for 2008. New York: United Nations. E/INCB/2008/1.

Kamminga J (2007) The political history of Turkey's opium licensing system for the production of medicines: Lessons for Afghanistan. Available at: http://www.poppyformedicine.net/modules/case_studies (accessed 11 March 2009). 
Windle, J. (2011). 'Poppies for Medicine in Afghanistan: Historical Lessons from India and Turkey'. Journal of Asian and African Studies. Vol. 46(6), pp. 663-677. Pre-print copy.

Kamminga J (2011) Opium poppy licensing in Turkey: A model to solve Afghanistan's illegal opium economy? Available at:

http://www.icosgroup.net/static/reports/Opium_Licensing_Turkey_Jorrit_Kamminga.p df(accessed 18 April 2011).

Kayaalp SO (2001) Success Stories in International Drug Control: Turkey. Unpublished document.

The Lancet (2005) Pragmatism over opium production in Afghanistan. The Lancet 366(9491): 1052.

Laurent L, Dusinberre D and Hoots C (1996) The Geopolitics of Drugs. Observetoire Geopolitique des Drogues. Boston, MA: Northeastern University Press.

Leeson R (2008) New ways to crack Afghan opium trade. The Australian 1 July.

Mansfield D (2001) An analysis of licit poppy cultivation: India and Turkey. Available at: www.geopium.org (accessed 5 December 2008).

Mansfield D (2007) Beyond the Metrics: Understanding the Nature of Change in the Rural Livelihoods of Opium Poppy Growing Households in the 2006/07 Growing Season. London: Afghan Drugs Interdepartmental Unit, Foreign and Commonwealth Office.

Murphy M and Steele R (1971) The World Heroin Problem. Washington, DC: US Government Printing Office.

Narcotics Control Board (NCB) (1993) Annual Report 1993. New Delhi: Government of India. Newman RK (1989) India and the Anglo-Chinese opium agreements, 1907-14. Modern Asian Studies 23(3): 525-60.

National Narcotics Intelligence Consumers Committee (NNICC) (1981) The Supply of Drugs to the US. Washington, DC: Drug Enforcement Agency.

National Narcotics Intelligence Consumers Committee (NNICC) (1988) The Supply of Illicit Drugs to the US. Washington, DC: Drug Enforcement Agency.

Paoli L, Greenfield V, Charles M and Reuter P (2009) The global diversion of pharmaceutical drugs. India: The third largest illicit opium producer?' Addiction 104: 347-54.

Patel S and Ross S (2007). Breaking point: Measuring progress in Afghanistan. Centre for Strategic and International Studies. Available at: http://www.csis.org/component/option,com_csis_pubs/task,view/id,3740/ (accessed 11 March 2009).

Polanyi J (2006) There's a way to end Afghanistan's and the worlds' pain. The Globe and Mail, 23 September 2006. 
Windle, J. (2011). 'Poppies for Medicine in Afghanistan: Historical Lessons from India and Turkey'. Journal of Asian and African Studies. Vol. 46(6), pp. 663-677. Pre-print copy.

Poroy I (1981) Expansion of opium production in Turkey and the state monopoly of 18281839. International Journal of Middle East Studies 13: 191-211.

Richards JF (1981) The Indian empire and peasant production of opium in the nineteenth century. Modern Asian Studies 15(1): 59-82.

Senlis Council (2007) Poppies for medicine. Available at:

http://www.icosgroup.net/modules/reports (accessed 11 April 2009).

Shaw M (2007) Drug trafficking and the development of organized crime in post-Taliban

Afghanistan. In: Buddenberg D, Byrd W (eds) Afghanistan's Drug Industry: Structure, Functioning, Dynamics and Implications for Counter-Narcotics Policy. New York:

World Bank and UNODC, 189-217.

Spain J (1975) The United States, Turkey and the poppy. The Middle East Journal 29(3): 295309.

Tanter R (2011) Out of the war: Eight steps to a sustainable peace in Afghanistan. Dissent 34: $11-16$.

United Nations (1961) Single convention on narcotic drugs. Available at: http://www.unodc.org/pdf/convention_1961_en.pdf (accessed 11 April 2007).

United Nations Office of Drugs and Crime (UNODC) (2008) Afghanistan opium survey 2008.

Available at: http://www.unodc.org/ (accessed 11 March 2009).

US State Department (2002) International Narcotics Control Strategy Report. Washington, DC: Bureau for International Narcotics and Law Enforcement.

US State Department (2007) Country reports on human rights practices. Available at: http://www.state.gov/g/drl/rls/hrrpt/2006/78868.htm (accessed 5 December 2008).

US State Department (2008) International Narcotics Control Strategy Report. Washington, DC: Bureau for International Narcotics and Law Enforcement.

US State Department (2009) International Narcotics Control Strategy Report. Washington, DC: Bureau for International Narcotics and Law Enforcement.

US State Department (2010) Country reports on human rights practices. Available at: http://www.state.gov/g/drl/rls/hrrpt/2010/index.htm (accessed 5 December 2008).

Van Ham P and Kamminga J (2007) Poppies for peace: Reforming Afghanistan's opium industry. Washington Quarterly 30(1): 69-81.

Wardak A (2006) Jirga - A traditional mechanism for conflict resolution in Afghanistan. Institute for Afghan Studies. Available at: http://www.institute-for-afghan-studies.org/ (accessed 8 June 2008). 
Windle, J. (2011). 'Poppies for Medicine in Afghanistan: Historical Lessons from India and Turkey'. Journal of Asian and African Studies. Vol. 46(6), pp. 663-677. Pre-print copy.

Watt G (1908) The Commercial Products of India. London: John Murray.

West CS (1992) Turkey and India. In: McDonald S, Zagarid B (eds) International Handbook on Drug Control. Westport: Greenwood Press.

Windle J (2011) Insights for contemporary drug policy: A historical account of opium control in India and Pakistan. Asian Journal of Criminology. 6(2): 1-20.

Windle J and Farrell G (2010) Criminal justice in Afghanistan. In: Newman G, Chung D, (eds) Crime and Punishment Around the World. Santa Barbara, CA: ABC-CLIO, 1-12.

Wishart D (1974) The opium poppy: The forbidden crop. Journal of Geography 73(1): 14-25.

World Bank (2008a) World Wide Governance Indicators. Available at: http://info.worldbank.org/governance/wgi2007/sc_country.asp (accessed 10 March 2009).

World Bank (2008b) The Afghanistan Transport Sector. Available at: http://go.worldbank.org/3058WF94E0 (accessed 10 March 2009). 